\title{
Antiepileptic and Antidepressant Activity of Majoon Najah (A Traditional Unani Formulation) in Experimental Animals
}

\author{
Mohd Urooj ${ }^{1, *}$, Gulam Mohammed Husain', Mohd. Nadeem ${ }^{1}$, Mohammed Abdul Rasheed Naikodi' ${ }^{2}$ Mahe Alam³, \\ Munawwar Husain Kazmi ${ }^{1}$ \\ 'Pharmacology Research Laboratory, National Research Institute of Unani Medicine for Skin Disorders, Hyderabad, Telangana, INDIA. \\ ${ }^{2}$ Drug Standardization Research Unit, National Research Institute of Unani Medicine for Skin Disorders, Hyderabad, Telangana, INDIA. \\ ${ }^{3}$ Central Council for Research in Unani Medicine, New Delhi, INDIA.
}

\begin{abstract}
Background: Majoon Najah is a polyherbal traditional Unani formulation recommended for the treatment of neurological disorders. To evaluate antiepileptic and antidepressant activity of majoon najah and majoon najah extract in experimental animals. Methods: Anticonvulsant activity was tested using maximal electroshock induced convulsion in male sprague dawley rats using diazepam $3 \mathrm{mg} / \mathrm{kg}$, p.o. as positive control. Pentylenetetrazole induced convulsion in swiss male albino mice was performed using phenytoin $25 \mathrm{mg} / \mathrm{kg}$ i.p. as positive control. The antidepressant activity of $\mathrm{MN}$ was evaluated using forced swim test model in male using Imipramine $20 \mathrm{mg} / \mathrm{kg}$, p.o. as positive control. Results: Antiepileptic study data showed reduction of all parameters like, tonic hind limb extension, clonic convulsion and stupor; however the values were not found statistically significant at all tested dose levels. The results of forced swim test model indicated that majoon najah effectively showed significant $(P<0.001)$ reduction in immobility duration in animals treated with majoon najah classical at dose $500 \mathrm{mg} / \mathrm{kg}$ bw and $1000 \mathrm{mg} / \mathrm{kg}$ bw as compared to
\end{abstract}

control rats. Conclusion: Based on above findings, it may be concluded that majoon najah did not showed effectiveness in epilepsy however, the results evident that majoon najah is a potential Unani formulation having antidepressant activity which may be preferred as an alternative therapy over modern medicine to treat depression.

Key words: Majoon Najah, Antiepileptic, Antidepressant, Polyherbal, Traditional medicine.

\section{Correspondence}

Dr. Mohd. Urooj

Research Officer (Pharmacology), Pharmacology Research Laboratory, National Research Institute of Unani Medicine for skin Disorders, Hyderabad 500038, Telangana, INDIA.

Phone no: +91-7088889991

Email: qaziurooj@gmail.com

DOI: 10.5330/ijpi.2020.3.70

\section{INTRODUCTION}

Majoon Najah $(\mathrm{MN})$ is a traditional semisolid polyherbal Unani formulation. It is a multicomponent Pharmacopoeial formulation mentioned in the National Formulary of Unani Medicine (NFUM), Part-I and other classical text of Unani system of medicine. It is recommended for the treatment of neurological disorders like, malikhuliya (Depression), Ikhtenaqurraham (hysteria), sara (Epilesy), Kutrib (psychosis), Junoon (schizophrenia), Juzam (leprosy), Dual-kulb (mania) and waja-ulmafasil (arthritis) .The key ingredient of $\mathrm{MN}$ is Triphala or Itrifal consisting of Post-e-Halela kabli (Terminalia chebula), Post-e-Balela (Terminalia bellerica) and Amla (Emblica officinalis). ${ }^{1}$ Today, millions of people globally are affected with neurological disorders such as epilepsy and depression. ${ }^{2}$ Around $80 \%$ people suffering from epilepsy in developing world do not get adequate treatment. Terminalia chebula and Terminalia bellerica has been traditionally used in Ayurvedic and Unani system of medicine primarily for gastrointestinal disorders. However, recently several studies were carried out on these ingredients to evaluate the protective effect against seizure and antidepressant activity in animals using classical form as well as extract., ${ }^{3,4}$ The third ingredient Amla (Emblica officinalis) has superior place in entire indigenous system including Ayurveda due to multifaceted clinical use. It is considered as one of the best source of Vitamin $\mathrm{C}$ and possesses antioxidant properties. Amla has been widely used as a nutraceutical in several diseases since it is known to boost immunity and offers numerous health benefits. Amla is one among all ingredients in Unani formulation used to treat mental disorders. ${ }^{5}$ Despite the advancement in pharmacotherapy of epilepsy and depression these disorders still do not have complete cure. The efficacy and safety of available therapy is questionable hence, there is an immense need for developing newer effective and safe alternative antiepileptic and antidepressant medications. Therefore, the current study was planned to confirm the antiepileptic and antidepressant activity of MN and MN extract using different animal models.

\section{MATERIALS AND METHODS}

\section{Composition of Formulation}

The following ingredients were presents in MN as per NFUM part I

\section{Preparation of Majoon Najah}

MN used in present study was prepared as per the standard Pharmacopoeial procedure in the GMP certified pharmacy of NRIUMSD Hyderabad. The Halailajat myrobalan fruits (Tirphala) from S.No 1 to 3 (Table 1) were dried to evaporate moisture content and minced into coarse powder and then passed through appropriate sieve. The powder obtained undergo the process of detoxification of Triphala known as rubbing (Tad'heen or Charb) using Raughan Zard (Cow Ghee). Remaining ingredients from S.No 4-8 (Table 1) were separately dried, powdered and sieved.

Formulation base called as Qiwam was prepared by adding $600 \mathrm{~g}$ sugar in $225 \mathrm{ml}$ of water. Then it is heated on low flame with continuous stirring until boiling of solution. Afterward, it is removed from heat 
and all the powdered ingredients $(300 \mathrm{~g})$ were mixed with it along with $2-3 \mathrm{~g}$ of benzoic acid as preservative. MN was ready to store in air tight container. ${ }^{1,6}$

\section{HPTLC Fingerprinting of Majoon Najah}

HPTLC of make Desaga Sarstedt Gruppe (Germany) was employed, pre coated silica gel $60 \mathrm{~F}_{254}$ Aluminium TLC plates (Merck, KgaA, Germany) was used. All the solvents used in the study were of HPLC grade. The $\mathrm{MN}$ formulation in different forms i.e. classical form and powdered ingredients of classical form without sugar were subjected to develop HPTLC fingerprinting.

\section{Majoon Najah Hydro-alcoholic extract}

$5 \mathrm{~g}$ of Majoon sample (Classical form) was taken and refluxed with 200 $\mathrm{ml}$ of alcohol: water (1:1) using soxhlet apparatus over heating mantle till the complete extraction was carried out. The content of extract was filtered and evaporated to concentrate up to $5 \mathrm{ml}$ and resultant was used as a sample for HPTLC analysis.

\section{Powdered ingredients of Majoon Najah(Classical) without sugar Hydro-alcoholic extract}

$5 \mathrm{~g}$ of sample powdered ingredients of $\mathrm{MN}$ was taken and refluxed with $200 \mathrm{ml}$ of alcohol: water (1:1) using soxhlet apparatus over heating mantle till the complete extraction was carried out. The content of extract was filtered and evaporated to concentrate up to $5 \mathrm{ml}$ and resultant was used as a sample for HPTLC analysis.

\section{Chromatographic Conditions}

HPTLC of make Desaga Sarstedt Gruppe (Germany) was employed in developing the fingerprinting profile of MN. The development Twintrough chamber was used $20 \mathrm{X} 10 \mathrm{~cm}$, Stationary phase was pre coated silica gel $60 \mathrm{~F}_{254}$ Aluminum plates (Merck, KgaA, Germany), Plate thickness was $0.2 \mathrm{~mm}$, Plate size was 200 x $100 \mathrm{~mm}$, Sample applied keeping distance $20 \mathrm{~mm}$ from starting edge and distance from bottom was kept as $10 \mathrm{~mm}$, Volume applied was $5 \mu \mathrm{l}$, band length kept as $10 \mathrm{~mm}$, distance between the tracks as $20 \mathrm{~mm}$ and TLC plate was developed up to the distance of $80 \mathrm{~mm}$. Mobile phase selected for the development of TLC plate was Toluene: Ethyl acetate: Methanol (7: 2: 1, v/v/v).

\section{Animals}

SD Rats (150-250 gm) and swiss albino mice (25-30 gm) were used for different animal models. The animals were procured from Edara Research Foundation, Hyderabad, India. All animals were housed in polycarbonate cages in the air conditioned room maintained at the temperature of $22^{\circ} \mathrm{C} \pm 3^{\circ} \mathrm{C}$ and relative humidity of $30-70 \%$, with a $12: 12$ $\mathrm{h}$ light/dark illumination cycle. ${ }^{7}$ Purpose of Control and Supervision of Experiments on Animals guidelines of laboratory animal care was followed throughout the experiment. ${ }^{8}$ Protocol of the study was approved by the Institutional Animals Ethics Committee vide protocol no. CRIUM/IAEC/2018/01/P05 dated 21.07.2018. Animals were provided unlimited supply of water and feed pellets (Amrut Laboratory Animal Diet, Krishna Valley Agrotech LLP, Pune, India). Animals were acclimatized to the laboratory conditions for one week before using them for experiment.

\section{Dose Selection}

The clinical dose of $\mathrm{MN}$ as mentioned in literature NFUM part1 is $5-10 \mathrm{~g}$ per day. Human dose of $5 \mathrm{~g}$ was used for dose translation (back calculation on the basis of body surface area) for study animals. ${ }^{9}$ Anticonvulsant activity was tested using maximal electroshock induced convulsion (MES) at the dose of 500 and $1000 \mathrm{mg} / \mathrm{kg}$ bw of classical
$\mathrm{MN}$ and 170 and $340 \mathrm{mg} / \mathrm{kg}$ bw of $50 \%$ hydro alcoholic extract using diazepam $3 \mathrm{mg} / \mathrm{kg}$, p.o. as positive control. Pentylenetetrazole (PTZ) induced convulsion model was performed in at the dose levels of 1000 and $2000 \mathrm{mg} / \mathrm{kg}$ bw of classical MN and 340 and $680 \mathrm{mg} / \mathrm{kg}$ bw of $50 \%$ hydro alcoholic extract using phenytoin $25 \mathrm{mg} / \mathrm{kg}$ i.p. was used as positive control.

The antidepressant activity of MN was evaluated using FST (forced swim test) model at dose of 500 and $1000 \mathrm{mg} / \mathrm{kg}$ bw of classical $\mathrm{MN}$ and 170 and $340 \mathrm{mg} / \mathrm{kg}$ bw of $50 \%$ hydro alcoholic extract using Imipramine 20 $\mathrm{mg} / \mathrm{kg}$, p.o. as positive control

\section{Drug Administration}

The test formulation MN and Positive control (Standard Drug) were administered by oral (gavage) for whole study duration as per study protocol schedule.

\section{Study Design and Procedure}

Maximal Electroshock Seizure - Induced Convulsion in Rats: Animals were divided into six groups of eight (8) rats each. Group I served as control and orally administered $0.3 \%$ CMC as vehicle. Group II was positive control which received Diazepam ( $3 \mathrm{mg} / \mathrm{kg}$, p.o.) continuously for seven days. Group III and IV were test dose groups for classical form of MN which were administered 500 and $1000 \mathrm{mg} / \mathrm{kg}$ bw per day respectively consecutively for seven days. Group V and VI were hydro alcoholic extract treated groups administered with 170 and $340 \mathrm{mg} / \mathrm{kg}$ bw per day, respectively, consecutively for seven days.

The electroshock was delivered to rats via ear-clip electrodes using digital electro-convulsiometer (Ugo Basile; Italy). The stimulus duration was $0.2 \mathrm{sec}$ and the current intensity was $150 \mathrm{mAmp}, 50$ hertz. Test was performed on $7^{\text {th }}$ day, 60 min after oral administration of $\mathrm{MN}$ or standard drug Diazepam. The animals were observed for the occurrence and duration of Tonic Hind Limb Extension (THLE) (sec), Duration of clonic convulsion (sec), Stupor (sec) and \% mortality for duration of 15 $\min .{ }^{10}$

Pentylenetetrazole induced convulsion in mice: Animals were divided into six groups of eight (8) animals each. Group I served as control orally treated with $0.3 \%$ CMC. Group II served as positive control and was treated with Phenytoin (25 mg/kg i.p.) continuously for seven days. Group III and IV were test dose groups for classical form of MN which were administered $1000 \mathrm{mg} / \mathrm{kg}$ bw per day and $2000 \mathrm{mg} / \mathrm{kg}$ bw per day respectively consecutively for seven days till the experiment day. Group $\mathrm{V}$ and VI were hydro alcoholic extract treated groups administered with 340 and $680 \mathrm{mg} / \mathrm{kg}$ bw per day respectively consecutively for seven days. Test was performed on $7^{\text {th }}$ day, PTZ $65 \mathrm{mg} / \mathrm{kg}$ bw was administered intraperitoneally $45 \mathrm{~min}$ after oral administration of vehicle or test formulation $(\mathrm{MN})$ and $30 \mathrm{~min}$ after administration of standard drug Phenytoin. Animal's epileptic behavior was observed for $30 \mathrm{~min}$ after PTZ administration and classified based on following scoring system. ${ }^{11}$

0: Normal behavior, no abnormality.

1: Immobilization, lying on belly.

2: Head nodding, facial, forelimb, or hind limb myoclonus.

3: Continuous whole-body myoclonus, Myoclonic jerks, tail held up stiffly.

4: Rearing, tonic seizure, falling down on its side.

5: Tonic-clonic seizure, falling down on its back, wild rushing and jumping.

6: Death.

Antidepressant activity using forced swim test in rats: Animals were divided into six groups of six animals each. Group I served as control and 
orally treated with $0.3 \% \mathrm{CMC}$ as vehicle. Group II was positive control which received Imipramine ( $20 \mathrm{mg} / \mathrm{kg}$ bw p.o.). Group III and IV were test dose groups for classical form of $\mathrm{MN}$ which were administered at the doses of 500 and $1000 \mathrm{mg} / \mathrm{kg}$ bw of MN per day consecutively for two weeks. Group V and VI were 50\% hydro-alcoholic extract treated groups administered with 170 and $340 \mathrm{mg} / \mathrm{kg}$ bw per day, respectively, for two weeks.

The test was carried out according to the method described in the literature ${ }^{11}$ the forced swim (also termed behavioral despair with slight modifications. Rats were forced to swim in a vessel $(20 \mathrm{~cm}$ diameter $\times 40$ $\mathrm{cm}$ high) filled with water at $24-26^{\circ} \mathrm{C}$. The total duration of immobility (seconds) was recorded in the test session. Rats were considered immobile when they made no attempts to escape except the movements necessary to keep their heads above the water (for floating). This method consisted of two sessions, the pretest and the test session, whereas in old method, the animals were subjected to direct immersion after administration of drugs, 40 min before test session. ${ }^{12}$

Pre-Test Session: On Day-1, $25 \mathrm{hr}$ prior to test session, the animals were placed in the experimental room at least $60 \mathrm{~min}$ before the beginning of the pretest session. In the pretest session, conducted on Day-1, the animals were allowed to swim individually for $15 \mathrm{~min}$ in vessel filled with water, after which the animals were removed, dried and returned to home cages.

Test Session: On the $2^{\text {nd }}$ day, test session was performed and each rat forced to swim for $5 \mathrm{~min}$ and duration of immobility was recorded (i.e., the time at which animal halts swimming, except for those movements which keep its head above water) through stop watch.

Two, pretest administrations of test substance/ vehicle at $24 \mathrm{hr}$ (i.e., after pretest session) and 60 min prior to the test session (i.e., Day-2) were used in the present study. Control animals were receiving the same frequency of vehicle administrations. Treatment was continued for two weeks and again another test session ( 5 min duration) was performed on $14^{\text {th }}$ day to observe the effect of test substance following repeated administration. ${ }^{13}$

\section{Statistical analysis}

The data obtained for various parameters were statistically evaluated by one way analysis of variance (ANOVA) followed by Tukey's multiple comparison as post hoc test. The mean values \pm SEM was calculated for each parameter. Level of significance was kept at $p<0.05$.

\section{RESULTS}

\section{HPTLC Fingerprinting}

In the MN sample extracts which are applied on TLC plate was developed in Toluene: Ethyl acetate: Methanol (7:2:1) for MN as shown in Figure 1. HPTLC densitogram the corresponding $\mathrm{R}_{f}$ values for the spots obtained were as shown in Table 2, Figure 2 and Figure 3. HPTLC revealed the presence of phytoconstituents having different $\mathrm{R}_{f}$ values and in TLC showed separated bands under UV $366 \mathrm{~nm}$. Upon detection under UV $366 \mathrm{~nm}$ the MN hydro-alcoholic extract shows three major spots at Rf values 0.61 (dark blue), 0.70 (blue), 0.77 (blue) and Powdered ingredients of MN (without sugar) hydro-alcoholic extract under UV $366 \mathrm{~nm}$ shows six spots at $\mathrm{R}_{f}$ values 0.06 (blue), 0.31 (pale yellow), 0.52 (blue) 0.61 (dark blue), 0.70 (blue), 0.77 (blue).

\section{Effect of (Majoon Najah Classical and Majoon Najah Extract) on electroshock induced convulsion in Rats}

The average duration of all measured parameters for all groups is presented in Figure 4. The results showed that there was a decrease in duration of THLE, clonic convulsion and stupor phase in MN treated group as compared to control group. However, there were no statistically significant reduction in both classical and extract treated animals at both dose levels as compared to animals of control group. The statistical significant reduction $(P<0.05$ or $P<0.01)$ were observed in positive control animals treated with diazepam as compared to control animals for all measured parameters.

\section{Effect of (Majoon Najah Classical and Majoon Najah Extract) on pentylenetetrazole induced convulsion in Mice}

The seizure score of epileptic behavior measured 30 min after PTZ administration showed reduction in all $\mathrm{MN}$ treated groups compared to control as shown in (Table 3). However, statistically significant reduction was observed only in phenytoin treated group as compared to control $(P$ $<0.01)$. Percent mortality in different treatment groups is mentioned in Table 3 .

\section{Effect of (Majoon Najah Classical and Majoon Najah Extract) on forced swim test in rats}

Swimming behavior was recorded following acute dose on $2^{\text {nd }}$ Day and after repeated drug administration on $14^{\text {th }}$ day. The results showed reduction in immobility duration and increase in swimming behavior in all treatment groups at all dose levels after administration of acute dose on $2^{\text {nd }}$ day. However, the decreased values were not found statistically significant as compared to control group (Figure 5). In contrast, there was statistically highly significant $(P<0.001)$ decrease in immobility duration in positive control (Imipramine $20 \mathrm{mg} / \mathrm{kg}$ bw) group and $\mathrm{MN}$ classical group at both dose level $500 \mathrm{mg} / \mathrm{kg}$ bw and $1000 \mathrm{mg} / \mathrm{kg} \mathrm{bw}$,

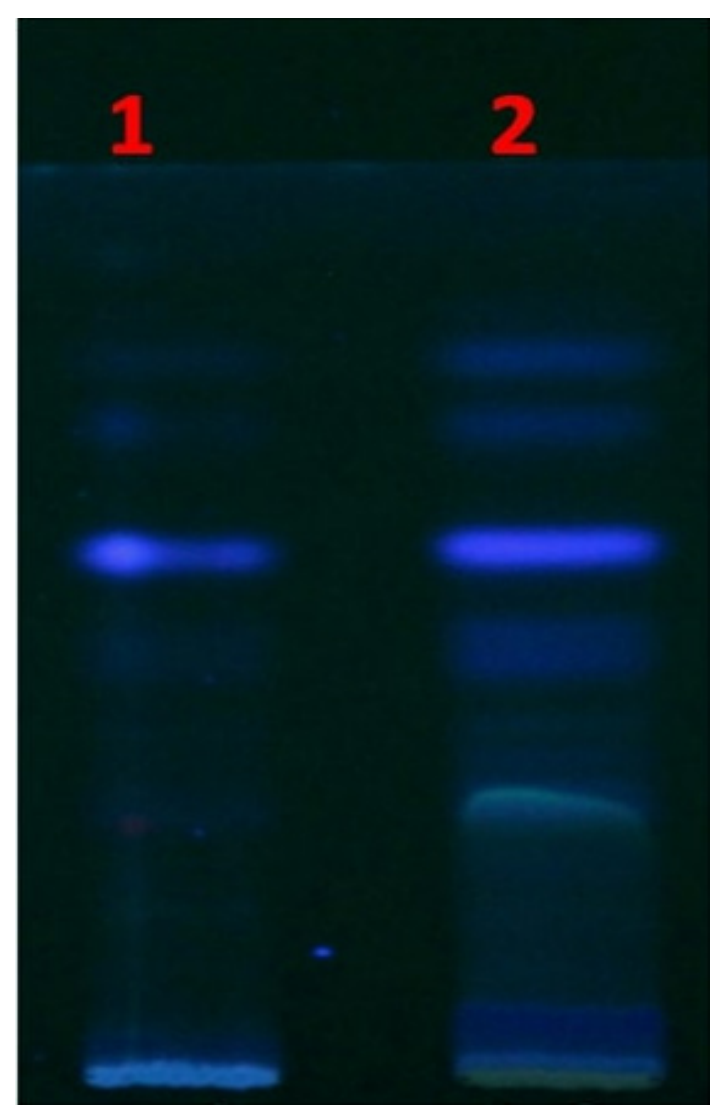

Figure 1: Chromatogram of MN Extracts.

1. MN Classical Hydro alcoholic extract

2. MN powdered ingredients (without sugar) Hydro alcoholic extracts 
Urooj, et al.: Pharmacological Evaluation of Majoon Najah

Table 1: Ingredients of MN.

\begin{tabular}{ccccc}
\hline S.No & Unani Name & Botanical Name & Part Used & Quantity (g) \\
\hline 1 & Post-e-halelakabli & Terminalia chebula Retz & Fruit & 50 \\
2 & Post-e-Balela & Terminalia bellerica Roxb & Fruit & 50 \\
3 & Aamla & Emblica officinalis Gaertn. & Fruit & 50 \\
4 & Halela Siyah & Terminalia chebula Retz & Fruit & 50 \\
5 & Turbud & Operculina turpethum Linn & Root & 25 \\
6 & Bisfayej & Polypodium vulgare Linn & Root & 25 \\
7 & Aftimoon & Cuscuta reflexa Roxb & Whole Plant & 25 \\
8 & Ustukhuddus & Lavandula stoechas Mill & Flowers & 25 \\
9 & Qandsafaid (Sugar) & & & 600 \\
\hline
\end{tabular}

Table 2: $\mathbf{R f}$ values for the spots found in MN Extracts.

\begin{tabular}{ccc|}
\hline Type of extract & $\begin{array}{c}\text { MN hydro-alcoholic } \\
\text { extract }\end{array}$ & $\begin{array}{c}\text { Powdered ingredients of } \\
\text { MN (without sugar) Hydro- } \\
\text { alcoholic extract }\end{array}$ \\
\hline $\begin{array}{c}\text { No. of spots } \\
\text { Peak no }\end{array}$ & 4 & 6 \\
1 & $\mathrm{R}_{f}$ values \\
2 & 0.02 & $\mathrm{R}_{f}$ values \\
3 & 0.57 & 0.02 \\
4 & 0.65 & 0.08 \\
5 & 0.96 & 0.31 \\
6 & -- & 0.58 \\
\hline
\end{tabular}

measured after repeated administration on $14^{\text {th }}$ day. The immobility duration was significantly reduced in extract high dose $(340 \mathrm{mg} / \mathrm{kg} \mathrm{bw})$ group (Mean \pm SEM: $31.33 \pm 1.667$ ), while no significant difference was observed in extract low dose $(170 \mathrm{mg} / \mathrm{kg} \mathrm{bw})$ group as compared to animals of control group.

\section{DISCUSSION}

$\mathrm{MN}$ is a traditional Unani formulation reported to be more effective for mental diseases which are caused due to excess of Sauda (black bile) ${ }^{14}$ In the present study we have tested the anticonvulsant and antidepressant activity in rodents. Data of antiepileptic study showed that in spite of reduction of THLE, clonic convulsion and stupor phase in rats, the values obtained were not found significantly different at any tested dose level for classical $\mathrm{MN}$ or $\mathrm{MN}$ extract ${ }^{15}$ reported significant reduction in THLE and seizure threshold in Increased Current Electroshock Seizure (ICES) method in Swiss albino mice at $1700 \mathrm{mg} / \mathrm{kg}$ bw of $\mathrm{MN}$ and $260 \mathrm{mg} / \mathrm{kg}$ bw of hydro ethanolic extract (ethanol and distilled water ratio 80:20) of MN following one week treatment. The observed difference in activity in our study may be attributable to variables like species difference (SD rats versus Swiss albino mice) and methodology adopted (MES at 150 mAmp in our study versus ICES upto $30 \mathrm{mAmp}$ current).In PTZ model, although mortality was reduced in all treated mice compared to vehicle treatment group, the seizures score in $\mathrm{MN}$ treated group animals was not statistically different as compared to control (though score was reduced). Phenytoin significantly reduced the seizures score compared to control group. Findings of our study are contrary to the reported antiepileptic effect of $\mathrm{MN}$ in mice. ${ }^{15}$

The antidepressant activity of MN was evaluated using FST model in rats. The results indicated that $\mathrm{MN}$ effectively showed significant $(P<0.001)$
Table 3: Effect of (MN Classical and MN Extract) on PTZ induced convulsion.

\begin{tabular}{ccc}
\hline Treatment Group $(n=8)$ & Seizure Score & \% Mortality \\
\hline Control & $5.38 \pm 0.26$ & 50 \\
Phenytoin $25 \mathrm{mg} / \mathrm{kg}$ & $2.13 \pm 0.58^{* *}$ & 12.50 \\
MN Classical $1000 \mathrm{mg} / \mathrm{kg}$ & $3.75 \pm 0.65$ & 25 \\
MN Classical $2000 \mathrm{mg} / \mathrm{kg}$ & $3.50 \pm 0.66$ & 25 \\
MN Extract $340 \mathrm{mg} / \mathrm{kg}$ & $3.63 \pm 0.53$ & 12.5 \\
MN Extract $680 \mathrm{mg} / \mathrm{kg}$ & $3.38 \pm 0.73$ & 25 \\
\hline
\end{tabular}

reduction in immobility duration in animals treated with $\mathrm{MN}$ classical at dose $500 \mathrm{mg} / \mathrm{kg}$ bw and $1000 \mathrm{mg} / \mathrm{kg}$ bw as compared to control rats. The MN extract showed significant $(P<0.001)$ reduction in immobility duration only at higher dose level $(340 \mathrm{mg} / \mathrm{kg}$ bw). These findings are in concurrence with the report of anti-depressant activity in tetrabenazine antagonism test and yohimbine toxicity enhancement test in mice following single dose of hydroethanolic extract of 260 and $520 \mathrm{mg} / \mathrm{kg}$ bw. ${ }^{16}$ The findings of yohimbine toxicity enhancement test suggested that yohimbine occupies central a 2 receptors and prevents noradrenaline from binding to $\mathrm{a} 2$ receptors, thus allowing an increase in noradrenaline release and concentration. ${ }^{16}$

There are several reports of antidepressant activity of various ingredients of MN with possible molecular mechanism. A study on aqueous extract of Emblica officinalis Gaertn (Amla) showed anti-depressant activity comparable to imipramine and fluoxetine in mice. Aqueous extract at the dose of 200 and $400 \mathrm{mg} / \mathrm{kg}$ bw for 14-days significantly reduced the immobility period in FST and tail suspension test in mice. ${ }^{17}$ The antidepressant effect of $E$. officinalis extract was significantly reversed by pretreatment of animals with prazosin ( $\alpha 1$-adrenoceptor antagonist), sulpiride (dopamine D2-receptor antagonist), p CPA (a serotonin synthesis inhibitor). Anti-depressant effect was attributed to inhibition of MAO-A and GABA. ${ }^{18}$ Aqueous extract (50, 100 and $200 \mathrm{mg} / \mathrm{kg}$ ) and ethanolic extract $(100 \mathrm{mg} / \mathrm{kg}$ ) of Terminalia bellirica Roxb., which is one of the chief ingredient of MN significantly reduced the immobility time of mice in FST and tail suspension test (TST) following 10-days oral administration. Both extracts reversed reserpine-induced extension of immobility period of mice in FST and TST. Prazosin $(62.5 \mathrm{microg} / \mathrm{kg}$, ip; an alpha1-adrenoceptor antagonist), sulpiride $(50 \mathrm{mg} / \mathrm{kg}$, ip; a selective D2 receptor antagonist) and p-chlorophenylalanine $(100 \mathrm{mg} / \mathrm{kg}$, ip; an 


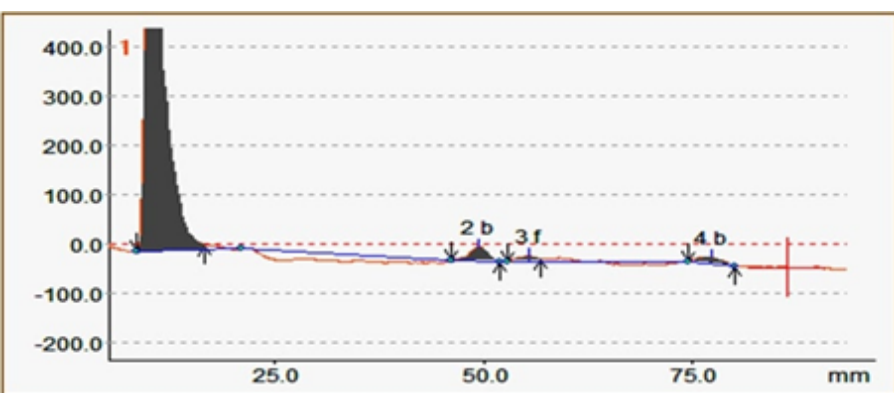

\begin{tabular}{|c|r|r|r|r|c|}
\hline Peak no & Y-Pos & \multicolumn{1}{c|}{ Area } & Area \% & Height & Rf value \\
\hline 1 & 10.6 & 1982.53 & 93.31 & 769.98 & 0.02 \\
\hline 2 & 49.4 & 71.97 & 3.39 & 28.36 & 0.57 \\
\hline 3 & 55.3 & 26.70 & 1.26 & 10.64 & 0.65 \\
\hline 4 & 77.2 & 43.47 & 2.05 & 12.77 & 0.96 \\
\hline
\end{tabular}

Figure 2: Densitogram of MN hydro alcoholic extract and peak listed at UV $366 \mathrm{~nm}$.

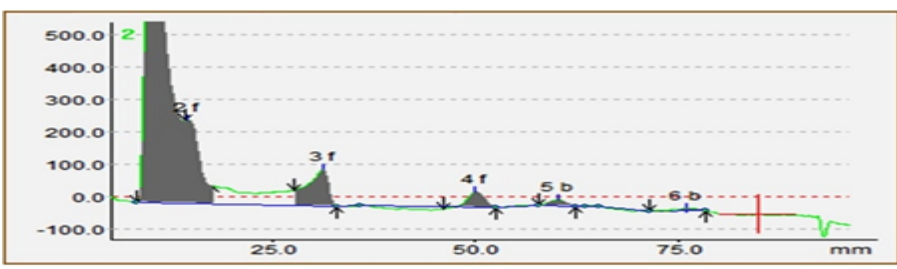

\begin{tabular}{|c|c|c|c|c|c|}
\hline Peak no & Y-Pos & \multicolumn{1}{|c|}{ Area } & Area \% & Height & Rf value \\
\hline 1 & 10.1 & 3407.89 & 77.34 & 1552.64 & 0.02 \\
\hline 2 & 14.5 & 490.78 & 11.14 & 251.83 & 0.08 \\
\hline 3 & 31.1 & 324.31 & 7.36 & 110.35 & 0.31 \\
\hline 4 & 50.0 & 110.25 & 2.50 & 48.37 & 0.58 \\
\hline 5 & 60.1 & 43.28 & 0.98 & 17.98 & 0.72 \\
\hline 6 & 75.9 & 29.63 & 0.67 & 8.35 & 0.94 \\
\hline
\end{tabular}

Figure 3: Densitogram of Powdered ingredients of MN (without sugar) hydro alcoholic extract and Peak listed at UV 366nm.

inhibitor of serotonin synthesis) significantly attenuated the aqueous and ethanolic extract-induced antidepressant-like effect in TST. Thus, both the aqueous and ethanolic extracts of T. bellirica elicited a significant antidepressant-like effect in mice by interaction with adrenergic, dopaminergic and serotonergic systems (Dhingra and Valecha, 2007). Another study reported that aqueous extracts of T. chebulaat 780 and $1560 \mathrm{mg} / \mathrm{kg}$ and Phyllanthus emblica at 1560 and $3120 \mathrm{mg} / \mathrm{kg}$ reduced immobility time in FST while in TST, $1560 \mathrm{mg} / \mathrm{kg}$ of T. chebula and $3120 \mathrm{mg} / \mathrm{kg}$ of $P$. emblica decreased immobility in mice. ${ }^{19}$

Methanolic extract of Cuscuta reflexa, another ingredients of $\mathrm{MN}$ has been reported to possess antidepressant activity in TST (EC $50 \sim 50 \mathrm{mg}$ / $\mathrm{kg}$ ) and this effect was attributed to quercetin mediated rise in neuronal serotonin and noradrenaline levels possibly via MAO inhibition. ${ }^{20}$ In another study, antidepressant-like effects of metabolites extracted (methanol) from the leaves of C. reflexa (200 and $400 \mathrm{mg} / \mathrm{kg}$ ) has been attributed either due to the inhibition of monoamine reuptake or significant suppression of HPA axis activation. ${ }^{21}$ Pre-treatment for 12 days with hydro alcoholic extract of aerial parts of Lavandula officinalis reduced immobility period in rats in a dose-dependent manner. ${ }^{22}$ Further, in a clinical study, subjects were given 2 cups of the infusion of 5 g dried Lavandula angustifilia (another species of Lavender) in addition to Citalopram $20 \mathrm{mg}$ twice a day. Lavandula angustifilia infusion has revealed positive therapeutic effects on depressed patients and decreased mean depression score. ${ }^{23}$

In light of reported studies, it may be concluded that multiple constituents present in ingredients of $\mathrm{MN}$ might interact with
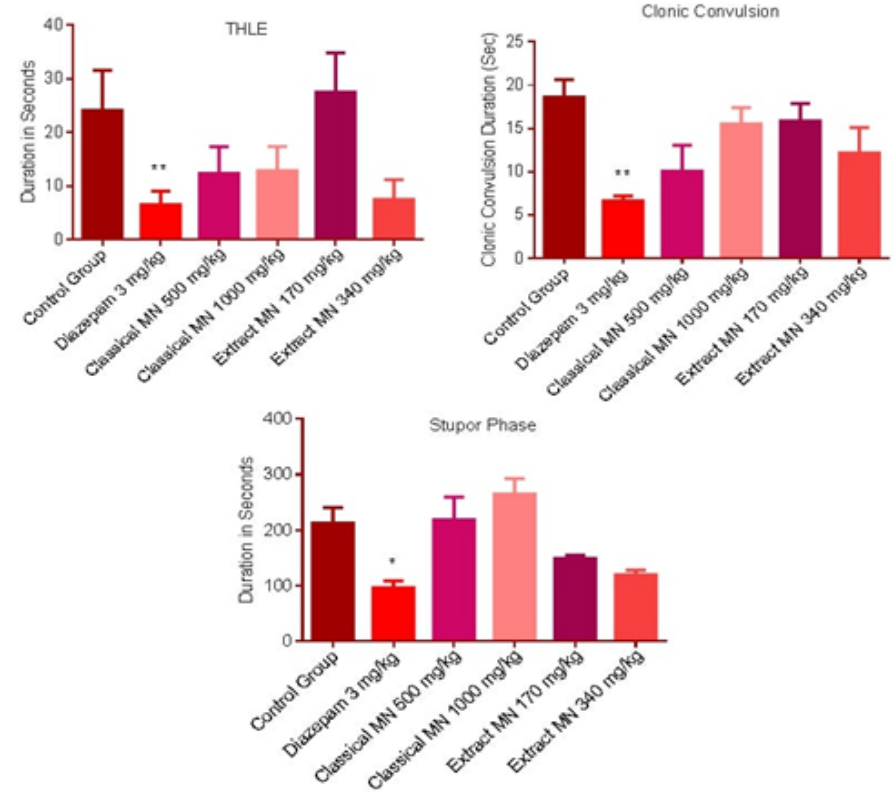

Figure 4: Parameters observed in MES model. Values were Mean \pm SEM $(n=8)$. Statistical significance was determined by ANOVA, followed by Tukey's multiple comparison-test, ${ }^{* *} P<0.01$ vs. control.

adrenergic, dopaminergic and serotonergic receptors and resulted in increase in level of nor epinephrine, dopamine and serotonin; and reduction in the levels of GABA in brains of animals. ${ }^{3}$ Hence it may be concluded that $\mathrm{MN}$ is a potential Unani formulation having antidepressant activity which may be preferred as an alternative therapy over modern medicine to treat depression.

The developed fingerprint profile of MN hydro alcoholic extracts showed that a spot at $\mathrm{R}_{f}$ value 0.31 is only observed in the hydro alcoholic extract of powdered ingredients of $\mathrm{MN}$ without sugar which is not seen in $\mathrm{MN}$ hydro-alcoholic extract representing a slight difference in the composition of sample extract.

\section{CONCLUSION}

HPTLC fingerprinting revealed active constituents at different $\mathrm{R}_{f}$ value for MN extract and MN dried powder without sugar. These results could be utilized as reference for future studies. Data obtained in antiepileptic activity test showed that the values obtained were not found significantly different at any tested dose level for classical MN or MN extract as compared to control. Further, the MN evident promising antidepressant effect in FST model at both tested dose level of $\mathrm{MN}$ and high dose level of MN extract. Therefore it may be concluded that MN did not possess antiepileptic effect while MN could be uses as potential Unani formulation having antidepressant activity which may be preferred as an alternative therapy over modern medicine to treat depression.

\section{ACKNOWLEDGEMENT}

We are grateful to the Director General, CCRUM, Ministry of AYUSH, Government of India, New Delhi, for financial and infrastructure support. We sincerely acknowledge support of Pharmacy division of CRIUM Hyderabad for providing MN formulation.

\section{CONFLICT OF INTEREST}

Authors declare no conflict of interest. 


\section{ABBREVIATIONS}

MN: Majoon Najah; NFUM: National Formulary of Unani Medicine; SD: Sprague Dawley; MES: Maximal Electroshock; PTZ: Pentylenetetrazol; FST: Forced Swim Test; TST: Tail Suspension Test; THLE: Tonic hind limb extension.

\section{REFERENCES}

1. Anonymous. National Formulary of Unani Medicine (NFUM), Part-I. 2006;104:138.

2. Reddy DS. Pharmacotherapy of catamenial epilepsy. Indian J Pharmacol. 2005;37(5):288. doi:10.4103/0253-7613.16851.

3. Husain I, Zameer S, Madaan T, Minhaj A, Ahmad W, labal I, et al. Exploring the multifaceted neuroprotective actions of Emblica officinalis (Amla): A Review. Metab Brain Dis. 2019;34(4):957-65. doi: 10.1007/s11011-019-00400-9.

4. Kumar R, Arora R, Agarwal A, Gupta YK. Protective effect of Terminalia chebula against Seizures, seizure-induced cognitive impairment and oxidative stress in experimental models of seizures in rats. J Ethnopharmacol. 2018;215:124-31. doi: 10.1016/j.jep.2017.12.008.

5. Nashine S, Kanodia R, Nesburn AB, Soman G, Kuppermann BD, Kenney MC. Nutraceutical effects of Emblica officinalis in Age-related macular degeneration. Aging. 2019;11(4):1177-88. doi: 10.18632/aging.101820

6. Afrin Z, Siddiqui A, Jafri MA, Vohora D, Asif M. Evaluation of anticonvulsant activity of MajoonNajah in experimental animal model. Asian J Pharm Pharmacol. 2019;5(4):660-8. doi: https://doi.org/10.31024/ajpp.2019.5.4.2

7. OECD, Test No. 408: Repeated Dose 90-Day Oral Toxicity Study in Rodents, OECD Publishing. 1998.

8. CPCSEA, Standard Operating Procedures (SOP) for IAEC. New Delhi: Committee for the Purpose of Control and Supervision of Experiments on Animals. 2010.

9. Reagan-Shaw S, Nihal M, Ahmad N. Dose translation from animal to human studies revisited. FASEB J. 2008;22(3):659-61. doi: 10.1096/fj.07-9574LSF.

10. Pourgholami M, Kamalinejad M, Javadi S, Majzoob MS. Evaluation of the anticonvulsant activity of the essential oil of Eugenia caryophyllata in male mice. J Ethnopharmacol. 1999;64(2):167-71. doi: 10.1016/s0378-8741(98)00121-4.

11. Shimada T, Yamagata K. Pentylenetetrazole-induced kindling mouse model. J Vis Exp. 2018;12(136):56573. doi: 10.3791/56573.

12. Porsolt RD, Pichon M, Jalfre $M$. Depression: A new animal model sensi- tive to

antidepressant treatments. Nature. 1977;266(5604):730-2 doi: $10.1038 / 266730 a 0$

13. Reddy MC, Gawade PS, Mohan RC. Evaluation of the effects of photooxidized Echiscarinatus venom on learning, memory and stress. J Venom Anim Toxins Incl Trop Dis. 2006;12(4):632-52. https://doi.org/10.1590/S16789992006000400010

14. Afrin Z, Siddiqui A, Jafri MA, Asif M, Jahan H. MajoonNajah: A Potent Unani Formulation for Neurological Disorders. EJBPS. 2017;4(7):198-206.

15. Afrin Z, Siddiqui A, Jafri MA, Vohora D, Asif M. Anticonvulsant Activity of Majoon Najah against PTZ Induced Seizure in Swiss Albino Mice. Int J Sci Res Bio Sci. 2018;5(6):170-9. https://doi.org/10.26438/ijsrbs/v5i6.170179.

16. Shariff FA, Jahan N, Hussain MT, Adiba M. Evaluation of antidepressant activity and the possible mechanism of action of majoonnajah in experimental models. Hippocratic Journal of Unani Med. 2015;10(3):9-23.

17. Dhingra D, Joshi $P$, Gupta A, Chhillar R. Possible involvement of monoaminergic neurotransmission in antidepressant-like activity of Emblica officinalis fruits in mice. CNS Neurosci Ther. 2012:18(5):419-25 doi:10.1111/i.17555949.2011.00256.x

18. Dhingra D, Valecha R. Evaluation of antidepressant-like activity of aqueous and ethanolic extracts of Terminalia bellirica Roxb. fruits in mice. Indian J Exp Biol. 2007;45(7):610-6

19. Pawar DB, Marathe PA, RegeNN. Antidepressant activity of aqueous extracts of fruits of Terminalia chebula and Phyllanthus emblica in behavioural models of depression: involvement of monoaminergic system. Int J Pharm Pharm Sci. 2014:6(8):615-20.

20. Zeeshan S, Zada W, Bhatti HA, Abbas G. Cuscutare flexa L. and Roxb.: An Implication of Quercetin Mediated Monoamine Oxidase Inhibition in Preclinical Models of Depression. Hamdard Medicus. 2016;59(1):5-11.

21. Adnan M, Chy MNU, Kamal ATMM, Chowdhury MR, Islam MS, Hossain MA et al. Unveiling Pharmacological Responses and Potential Targets Insights of Identified Bioactive Constituents of Cuscutare flexa Roxb. Leaves through in vivo and in silico Approaches. Pharmaceuticals. 2020;13(3):50. doi: 10.3390/ ph13030050.

22. Rahmati B, Kiasalari Z, Roghani M, Khalili M, Ansari F. Antidepressant and anxiolytic activity of Lavandulam officinalis aerial parts hydroalcoholic extract in scopolamine-treated rats. Pharm Biol. 2017;55(1):958-65. doi: 10.1080/13880209.2017.1285320.

23. Nikfarjam M, Parvin N, Assarzadegan N, Asghari S. The Effects of Lavandula an gustifolia Mill Infusion on Depression in Patients Using Citalopram: A comparison Study. Iran Red Crescent Med J. 2013;15(8):734-9. doi: 10.5812/ircmj.4173.

Article History: Submission Date : 26-06-2020; Revised Date : 14-07-2020; Acceptance Date : 16-08-2020.

Cite this article: Urooj M, Husain GM, Nadeem M, Naikodi MAR, Alam M, Kazmi MH. Antiepileptic and Antidepressant Activity of Majoon Najah (A Traditional Unani Formulation) in Experimental Animals. Int. J. Pharm. Investigation, 2020;10(3):396-40 